\title{
The energy-saving modification program of lighting equipment based on the economic evaluation
}

\author{
Yuan Yang \\ Institute of Electrical and Information, Jinan University \\ Zhuhai 519070, Guangdong, P. R. China \\ Email: 826556527@qq.com \\ Wei-hua Li, Xin-zheng Zhang, Chu-qi Yang, Dong Lv,Hai-qiang Liao, Lin Yang \\ Institute of Electrical and Information, Jinan University \\ Zhuhai 519070, Guangdong, P. R. China \\ Email:18145793@qq.com
}

\begin{abstract}
Considering many lighting energy-saving modification programs have the phenomenon of diseconomy; this paper takes into account economic evaluation to solve this problem. The optimal program of total energy-saving benefit will be found under the limited investment according to economic evaluation of the price, life span and power consumption of lighting equipments. Firstly, the benefit ratio will be used to evaluate on the necessity of modification, and get the order. If the biggest benefit ratio exists in different equipments simultaneously, the better one will be selected in terms of relative payback period of investment. And on the basis, the relative remaining time is innovatively introduced into economic evaluation to determine the locations of modification. Then an example from a factory can prove that the program is workable.
\end{abstract}

Index Terms-lighting modification, economic evaluation, energy-saving benefit

\section{INTRODUCTION}

The Chinese government takes "building a resource saving and environmentally friendly society" as the basic national policy, which means that our country enters the period of an energy-saving society. Thus many users have modified their lighting equipment opportunely in order to save energy. But many energy-saving modification programs have the embarrassment of diseconomy according to investigation [1]. Why? The quality of lighting equipment is rather irregularity in the Chinese market. What's worse, users modify the lighting equipment blindly without the foundation of the energysaving benefit [1], [2].

Thus, the users have to evaluate the effect of energysaving modification from economic view. Economic analysis is to calculate, analyze and evaluate the economic effects on energy saving programs, so users can choose the optimal program [3]. According to statistics, the common methods are life cycle cost method, payback period method and net present value method, which are used to evaluate the economy of program [4-7]. (i) The life cycle cost method pursues the minimum discounted cost, which is suitable to comparative evaluation of various programs [8], [9]. (ii) The payback period method evaluates the effect of investment, and the speed of return can be seen from the payback period directly [10-12]. (iii) The net present value method valuates the short-term and certain investment project, which is calculated by discount rate of the capital cost [13]. However, the speed of payback period can't be seen through life cycle method. The payback period method doesn't take the effective discount rate into account. In practical application, there's a great deviation between the anticipated investment and the reality with the method of the net present value [14-17]. Thus this paper combines the advantages of these major methods, and introduces three indexes which include benefit ratio, relative payback period of investment and relative remaining time to evaluate the economic benefit and get the optimal modification program.

\section{THE PRINCIPLES OF MODIFICATION}

\section{A. Figures and Tables}

Lighting equipment can be divided into five types: incandescent, fluorescent (T12/T8/T5/compact fluorescent lamps), high-pressure mercury lamp, highpressure sodium (HPS), metal halide lamp (MH). Ballasts include electronic ballast and magnetic ballast [18]. Thus this paper cites four factors, which include price, power consumption, life span and running time, to establish the economic evaluation to get the optimal energy-saving modification program of lighting equipment.

This paper concerns about three indexes, including benefit ratio, relative payback period of investment and relative remaining time. Generally, users can't carry out the modification of lighting equipment completely due to limited fund. Therefore, the corresponding principles of modification are introduced in this paper to work out the optimal program of saving energy. These principles are as follows. 
(i) Only when the benefit ratio of the equipment is above 0 can it be modified. The larger the benefit ratio of the equipment is the better the benefit of saving energy is. There's no doubt that the equipment, which has the maximum benefit ratio, should be modified first. Thus, benefit ratios should be followed by the principle, which is the ranking from the largest down to the smallest. Based on the benefit ratios, the best brand of lighting equipment and their modification order can be obtained.

(ii) If the maximum benefit ratio exists in different equipment, the equipment with minimum relative payback period of investment should have priority to be modified. The shorter the relative payback period is, the shorter its investment recover time is. Thus, relative payback period should be followed by the principle, which is the ranking from the shortest to the longest.

(iii) When the largest benefit ratio and shortest relative payback period of investment are found in different equipments, they will enjoy the same right to be modified. On the basis, the specific location of modification will be decided in terms of relative remaining time. If the relative remaining time of the equipment is shorter, its chance to be scrap is bigger. Thus it should be modified first.

What must be emphasized here is that the relationships among these three indexes are subordinate. The relative payback period of investment is subordinate to the benefit ratio, and the relative remaining time is subordinate to the relative payback period of investment. If the benefit ratio of equipment $A$ is larger than that of equipment $B$ even though the relative payback period of investment of $B$ is much shorter than $A, A$ still has priority to be modified. In the same way, if the relative payback period of investment of equipment $A$ is shorter than that of equipment $B$ on the condition that they has the same benefit ratio even though the relative remaining time of $B$ is much shorter than that of $A, A$ should be considered firstly to be modified.

\section{BASED ON ECONOMIC EVALUATION OF LIGHTING MODIFICATION PROGRAM}

In this paper, the equipment which has less power consumption than current-used lighting equipment can be called energy-saving lighting equipment in terms of the same luminous flux. The energy saving can be calculated by the power conversion relationship between energysaving lighting equipment and current-used lighting equipment, and then their energy-saving benefit can be obtained.

\section{A. Energy-saving benefit}

1) The relationship of power conversion among lighting equipment[18]
TABLE I. THE RELATIONSHIP OF POWER CONVERSION

\begin{tabular}{c|c|c}
\hline \multicolumn{2}{c|}{ Equipment } & Alternative Product \\
\hline \multirow{2}{*}{ T12 } & $20 \mathrm{~W}$ & Incandescent $40 \mathrm{~W}$ \\
\cline { 2 - 3 } & $40 \mathrm{~W}$ & Incandescent $60 \mathrm{~W}$ \\
\hline \multirow{2}{*}{ T5 } & $14 \mathrm{~W}$ & T12/20W or Incandescent $40 \mathrm{~W}$ \\
\cline { 2 - 3 } & $28 \mathrm{~W}$ & T12/40W or Incandescent $60 \mathrm{~W}$ \\
\hline \multirow{2}{*}{ CFL } & $9 \mathrm{~W}$ & $\begin{array}{c}\text { Incandescent } 40 \mathrm{~W} \text { or T12/20W or } \\
\text { T5/14W }\end{array}$ \\
\cline { 2 - 3 } & $11 \mathrm{~W}$ & $\begin{array}{c}\text { Incandescent } 60 \mathrm{~W} \text { or T12/20W or } \\
\mathrm{T} 5 / 28 \mathrm{~W}\end{array}$ \\
\hline \multirow{2}{*}{ HPS } & $125 \mathrm{~W}$ & $\mathrm{HPM} / 250 \mathrm{~W}$ \\
\cline { 2 - 3 } & $200 \mathrm{~W}$ & $\mathrm{HPM} / 400 \mathrm{~W}$ \\
\hline
\end{tabular}

T12: coarse diameter fluorescent; T5: small diameter fluorescent lamp; CFL: compact fluorescent lamp; HPS: high-pressure sodium lamp; HPM: high-pressure mercury lamp.

According to power conversion relationship, the energy saving of energy-saving equipment can be obtained in terms of the same luminous flux.

2) The energy saving [4]

$$
\Delta A_{i}^{\prime}=a_{i}^{\prime}-a_{i} \quad(i=1,2,3, \cdots, m)
$$

$\Delta A_{i}^{\prime}$ stands for the amount of unit-hour energy saving after replacing current-used lighting equipment $i$, hour/kilowatt; $a_{i}$ stands for unit-hour power consumption of current-used lighting equipment $i ; a_{i}^{\prime}$ stands for unithour power consumption of energy-saving lighting equipment that replaces current-used lighting equipment $i$ in terms of the same luminous flux; $m$ stands for the total number of lighting equipment which are replaced.

After the amount of energy saving is obtained, energysaving benefit of unit energy-saving lighting equipment can be calculated according to the price of electricity, investment cost, discount rate and life span. And there will be a conclusion whether to modify the equipment in terms of the energy-saving benefit.

3) The energy-saving benefit of unit energy-saving lighting equipment

The present value of energy-saving benefit of the lighting equipment $i$ in $t$ year is that the energy-saving benefit in $t$ year minus the assessed cost of total investment in $t$ year. 
$M_{i}^{\prime}=\sum_{t=1}^{n_{i}} M_{i t}^{\prime}$

$$
\left\{\begin{array}{l}
M_{i t}^{\prime}=\left(P_{t} \cdot \Delta A_{i}^{\prime} \cdot T_{i t}^{\prime}-c_{i t}^{\prime}\right) \cdot\left(1+i_{s}\right)^{-t} \\
c_{i t}^{\prime}=\frac{p_{i}^{\prime}+\sum_{t=1}^{n_{i}} m_{i t}^{\prime}}{T_{i}^{\prime}}, T_{i}^{\prime}=\sum_{t=1}^{n_{i}} T_{i t}^{\prime}
\end{array} \quad\left(t=1,2,3, \cdots, n_{i}\right)\right.
$$

Where, $M_{i}^{\prime}$ is the present value of energy-saving benefit after replacing current-used lighting equipment $i$, $¥ ; M_{i t}^{\prime}$ is the present value of energy-saving benefit in the year $t$ after replacing current-used lighting equipment $i, ¥ ; P_{t}$ is the price of electricity in the year $t$, $Y /(\mathrm{kW} \cdot \mathrm{h}) ; C_{i t}^{\prime}$ is the assessed cost of total investment in the year $t, Y ; T_{i t}^{\prime}$ is the running time in the year $t$, and the total running time of each year based on past data, hours; $p_{i}$ is the price of current-used lighting equipment $i ; p_{i}^{\prime}$ is the price of energy-saving lighting equipment; $m_{i t}^{\prime}$ is the maintenance cost in the year $t$ and treated as fixed value; $T_{i}$ is the life span of current-used lighting equipment $i ; T_{i}^{\prime}$ is the life span of energy-saving lighting equipment; $i_{s}$ is the discount rate, $\% ; n_{i}$ is the total running years of energy-saving lighting equipment.

In order to simplify process, the investment only includes the price of energy-saving lighting equipment. That means their maintenance cost is out of consideration. And supposing annual running time of lighting equipment is fixed and the price of electricity of per kilowatt-hour keeps $1 ¥$. And overall discount rate is $10 \%$.

(i) When the replacement occurs to lighting equipment with different power, energy-saving benefit $M_{i}^{\prime}$ equals $\left(P_{t} \cdot \Delta A_{i}^{\prime} \cdot T_{i}^{\prime}\right) /(1+10 \%)-p c_{i}^{\prime}$.

For example, the life span of $\mathrm{T} 8 / 18 \mathrm{~W}$ is 10,000 hours, and its purchase price is $10 \mathrm{Y}$. When $\mathrm{T} 8 / 18 \mathrm{~W}$ replaces T12/20W, energy-saving benefit $M_{i}^{\prime}$ equals $(20-18) \times 8500 /(1000 \cdot(1+10 \%))-10=6.3 ¥$.

(ii) When the power between current-used lighting equipment and energy-saving lighting equipment is the same, energy-saving benefit $M_{i}^{\prime}$ equals $\left(p_{i} / T_{i} \cdot T_{i}^{\prime}\right) /(1+10 \%)-p_{i}^{\prime}$.

\section{B. The economic evaluation of energy-saving benefit}

The benefit ratio can be calculated by energy-saving benefit of unit energy-saving lighting equipment, and then put the equipment for modification in order. Benefit ratio is the ratio of total benefit to total investment. The energy-saving equipment that has the maximum benefit ratio should get priority to be modified.

$$
\begin{aligned}
& B_{i}^{\prime}=O_{i}^{\prime} / C_{i}^{\prime}=M_{i}^{\prime} / p_{i}^{\prime} \\
& \left\{\begin{array}{l}
N_{i}^{\prime}=C_{i}^{\prime} / p_{i}^{\prime} \\
O_{i}^{\prime}=N_{i}^{\prime} \cdot M_{i}^{\prime}, \text { and } I_{i}^{\prime} \geq p_{i}^{\prime}
\end{array}\right.
\end{aligned}
$$

Where, $B_{i}^{\prime}$ is the benefit ratio; $O_{i}^{\prime}$ is the total benefit; $C_{i}^{\prime}$ is the total cost including only purchase cost of energy-saving lighting equipment; $N_{i}^{\prime}$ is the amount of energy-saving lighting equipment.

After the benefit ratio is obtained, the relative payback period of investment is introduced to solve the problem that the maximum benefit ratio occurs to different types of energy-saving equipment. The relative payback period of investment can be calculated by annual running time and life span.

$R_{i}^{\prime}=I_{i}^{\prime} / A_{i}^{\prime}$

$\left\{\begin{array}{l}I_{i}^{\prime}=p_{i}^{\prime} /\left(\Delta A_{i}^{\prime} \cdot P_{t}\right) \\ A_{i}^{\prime}=T_{i}^{\prime} / n_{i}\end{array}\right.$

Where, $I_{i}^{\prime}$ is the investment payback period, hours; $R_{i}^{\prime}$ is the relative payback period of investment, it is the ratio of investment payback period to annual running time; $A_{i}^{\prime}$ is annual running time, hours. Supposing the annual running time is the same, so $T_{i t}^{\prime}=A_{i}=A_{i}^{\prime}$.

After the benefit ratio and relative payback period of investment are obtained, relative remaining time is introduced to solve the problem that how to make sure the specific location in modification. Relative remaining time is the ratio of remaining life span to annual running time.

$R_{i j}=\left(T_{i}-T_{i j}\right) / a_{i j} \quad(j=1, \cdots, n)$

Where, $R_{i j}$ is the relative remaining time of lighting equipment $i$ in location $j ; T_{i}$ is the life span of lighting equipment $i ; T_{i j}$ is the total running time of lighting equipment $i$ in location $j ; a_{i j}$ is the annual running time of lighting equipment $i$ in location $j$, hours.

\section{The determination of program}

According to the principles of modification mentioned above, the benefit ratio can select the best brand of energy-saving lighting equipment, and get the order of modification in current-used equipments. When the maximum benefit ratio exists in different types of lighting equipment, the relative payback period of investment will be introduced to find out the best one for modification. On this basis, the relative remaining time will be considered to decide the specific locations for modification. Therefore, the optimal energy-saving program can be obtained from these three indexes. 
The determination of energy-saving modification program has four key factors: investment, objects, time and locations. The investment in real life is often limited. Even if a program can produce the largest benefit ratio, it has to be abandoned when the cost is larger than the investment. Therefore, this paper proposes how to decide the best modification program from the angle of limited investment and makes users timely adjust the optimal program under limited fund. This paper only modifies the current-used lighting equipment by assuming that the modification time is current. After such a simplification, the determination of program needs only two key factors: the modification objects and the locations.

When the total value of energy-saving benefit is the only consideration, the maximum benefit of modification program can only be obtained on the condition of unlimited fund. Thus the energy-saving benefit of unit lighting equipment can be obtained through the benefit ratio. The relative value's real advantage over total value is that it pursues the optimization of unit investment. Therefore, when comparing the benefit ratios of different equipments, the paper can directly reflect the benefit of each of equipment under limited investment that helps users to choose the best one. When comparing the relative payback periods of investment of different equipments with their annual-running time, the paper can help users to choose the best one. The modification locations can be determined by the modification urgency of various regions' equipments, which is reflected by relative remaining time.

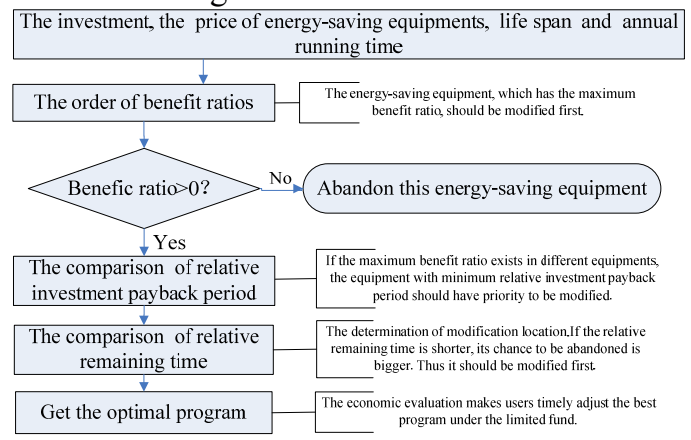

Figure 1. The flowchart of system operation

From Fig.1, the optimal program process is as follows. Firstly, the amount of energy saving can be calculated by power conversion. And the energy-saving benefit of unit lighting equipment can be calculated by the price of electricity, the investment, discount rate and life span. Secondly, the benefit ratios of lighting equipment of various brands can be seen in terms of unit equipment's price, energy-saving benefit and life span. Thirdly, relative payback period of investment can be worked out according to life span, price and annual running time. Lastly, the relative remaining time can be acquired in accordance with life span, annual running time of different locations. Then the optimal energy-saving program can be worked out by economic evaluation based on the principles of modification.

\section{THE EXAMPLE ANALYSIS}

According to the actual conditions of different types of lighting equipment and a factory, the optimal program can be obtained through three indexes mentioned above.

\section{A. The modification order of lighting equipment}

Based on the survey, the price and life span of different types of lighting equipment can be obtained as follows in Table II.

TABLE II. THE PRICE AND LIFE SPAN OF DIFFERENT TYPES OF LIGHTING EQUIPMENT [19]

\begin{tabular}{cccccc}
\hline $\begin{array}{c}\text { Lighting } \\
\text { equipment }\end{array}$ & $\begin{array}{c}\text { Life } \\
\text { span(hour) }\end{array}$ & $\operatorname{Price}(Y)$ & $\begin{array}{c}\text { Lighting } \\
\text { equipment }\end{array}$ & $\begin{array}{c}\text { Life } \\
\text { span(hour) }\end{array}$ & $\operatorname{Price}(Y)$ \\
\hline $\begin{array}{c}\text { Incandescent } \\
\text { 40W }\end{array}$ & 800 & 4 & CFL/9W & 2200 & 10.5 \\
\hline $\begin{array}{c}\text { Incandescent } \\
60 \mathrm{~W}\end{array}$ & 800 & 4 & $\mathrm{CFL} / 11 \mathrm{~W}$ & 2200 & 10.5 \\
\hline $\mathrm{T} 12 / 20 \mathrm{~W}$ & 1800 & 10 & $\mathrm{HPM} / 250 \mathrm{~W}$ & 3000 & 58 \\
\hline $\mathrm{T} 12 / 40 \mathrm{~W}$ & 1800 & 10 & $\mathrm{HPM} / 400 \mathrm{~W}$ & 3000 & 58 \\
\hline $\mathrm{T} 5 / 14 \mathrm{~W}$ & 2500 & 12 & $\mathrm{HPS} / 125 \mathrm{~W}$ & 3600 & 100 \\
\hline $\mathrm{T} 5 / 28 \mathrm{~W}$ & 2500 & 12 & $\mathrm{HPS} / 200 \mathrm{~W}$ & 3600 & 100 \\
\hline
\end{tabular}

The energy-saving benefit, the price and the benefit ratio of unit energy-saving equipment can be obtained from Table I, Table II and equation (3). The energysaving equipment, which has the maximum benefit ratio, should be modified first. And when the benefit ratio of energy-saving lighting equipment is below zero, this equipment should be abandoned. The conclusion can be drawn as follows.

TABLE III. THE DECISION OF MODIFICATION OBJECTS

\begin{tabular}{|c|c|c|c|c|c|}
\hline Current-used & $\begin{array}{c}\text { Possible } \\
\text { combination }\end{array}$ & Benefit & Price & $\begin{array}{c}\text { Benefit } \\
\text { ratio }\end{array}$ & Conclusion \\
\hline \multirow{3}{*}{$\begin{array}{c}\text { Incandescent } \\
40 \mathrm{~W}\end{array}$} & CFL/9W & 20.50 & 10.5 & 1.952 & \multirow{3}{*}{$\begin{array}{c}\text { Replace } \\
\text { Incandescent } \\
\text { 40W with } \\
\text { CFL/9W }\end{array}$} \\
\hline & $\mathrm{T} 12 / 20 \mathrm{~W}$ & 6.36 & 10 & 0.636 & \\
\hline & T5/14W & 17.55 & 12 & 1.462 & \\
\hline \multirow{3}{*}{$\begin{array}{c}\text { Incandescent } \\
60 \mathrm{~W}\end{array}$} & CFL/11W & 38.50 & 10.5 & 3.667 & \multirow{3}{*}{$\begin{array}{c}\text { Replace } \\
\text { Incandescent } \\
60 \mathrm{~W} \text { with } \\
\mathrm{CFL} / 11 \mathrm{~W}\end{array}$} \\
\hline & $\mathrm{T} 12 / 40 \mathrm{~W}$ & 6.36 & 10 & 0.636 & \\
\hline & $\mathrm{T} 5 / 28 \mathrm{~W}$ & 24.36 & 12 & 2.030 & \\
\hline \multirow{2}{*}{$\mathrm{T} 12 / 20 \mathrm{~W}$} & CFL/9W & 0.50 & 10.5 & 0.048 & \multirow{2}{*}{$\begin{array}{c}\text { Replace } \\
\text { T12/20W with } \\
\text { CFL/9W }\end{array}$} \\
\hline & $\mathrm{T} 5 / 14 \mathrm{~W}$ & -5.18 & 12 & -0.432 & \\
\hline \multirow{2}{*}{$\mathrm{T} 12 / 40 \mathrm{~W}$} & CFL/11W & 18.50 & 10.5 & 1.762 & \multirow{2}{*}{$\begin{array}{c}\text { Replace } \\
\text { T12/40W with } \\
\text { CFL/11W }\end{array}$} \\
\hline & T5/28W & 1.64 & 12 & 0.136 & \\
\hline $\mathrm{T} 5 / 14 \mathrm{~W}$ & CFL/9W & -5.50 & 10.5 & -0.524 & $\begin{array}{l}\text { Not to be } \\
\text { modified }\end{array}$ \\
\hline $\mathrm{T} 5 / 28 \mathrm{~W}$ & CFL/11W & 14.50 & 10.5 & 1.381 & Be modified \\
\hline $\mathrm{HPM} / 250 \mathrm{~W}$ & HPS/125W & 104.55 & 100 & 1.045 & Be modified \\
\hline $\mathrm{HPM} / 400 \mathrm{~W}$ & $\mathrm{HPS} / 200 \mathrm{~W}$ & 227.27 & 100 & 2.273 & Be modified \\
\hline
\end{tabular}

Note: benefit here is that the present energy-saving benefit of unit lighting equipment after deducting its cost.

The best energy-saving equipment to replace currentused lighting equipment can be obtained from Table III. 


\section{B. The optimal program for modification of lighting equipment}

The investment for improving current-used lighting equipment is 45,000 $¥$. The optimal energy-saving program can be worked out in terms of the investment and modification objects. Table IV reflects the current lighting conditions in a factory.

TABLE IV. THE CONCRETE CONDITIONS OF LIGHTING EQUIPMENT IN THE FACTORY

\begin{tabular}{|c|c|c|c|c|c|}
\hline Area & Current-used & Quantity & $\begin{array}{l}\text { Life } \\
\text { span } \\
\text { (h) }\end{array}$ & $\begin{array}{l}\text { Annual } \\
\text { running } \\
\text { time(h) }\end{array}$ & $\begin{array}{l}\text { Total } \\
\text { running } \\
\text { time }(\mathrm{h})\end{array}$ \\
\hline Plant A & $\begin{array}{c}\text { Incandescent } \\
60 \mathrm{~W}\end{array}$ & 200 & 800 & 400 & 500 \\
\hline Plant B & $\begin{array}{c}\text { Incandescent } \\
60 \mathrm{~W}\end{array}$ & 200 & 800 & 200 & 750 \\
\hline Plant C & $\begin{array}{c}\text { Incandescent } \\
40 \mathrm{~W}\end{array}$ & 200 & 800 & 200 & 750 \\
\hline Plant D & $\mathrm{T} 12 / 40 \mathrm{~W}$ & 200 & 1800 & 1000 & 1600 \\
\hline Plant E & $\mathrm{T} 12 / 20 \mathrm{~W}$ & 200 & 1800 & 1000 & 1200 \\
\hline Plant F & $\mathrm{T} 12 / 20 \mathrm{~W}$ & 200 & 1800 & 1000 & 800 \\
\hline Plant G & $\mathrm{T} 5 / 14 \mathrm{~W}$ & 200 & 2500 & 2000 & 1500 \\
\hline Plant $\mathrm{H}$ & $\mathrm{T} 5 / 28 \mathrm{~W}$ & 200 & 2500 & 2000 & 1500 \\
\hline Street I & HPM/250W & 400 & 3000 & 800 & 1500 \\
\hline Street J & HPM/400W & 400 & 3000 & 800 & 1500 \\
\hline
\end{tabular}

The modification order of lighting equipment in each area of the factory can be obtained by the economic evaluation from Table III and Table IV.

TABLE V. THE MODIFICATION ORDER OF LIGHTING EQUIPMENT

\begin{tabular}{ccccccc}
\hline Area Current-used & $\begin{array}{c}\text { Payback } \\
\text { period } \\
\text { (h) }\end{array}$ & $\begin{array}{c}\text { Benefit } \\
\text { ratio }\end{array}$ & $\begin{array}{c}\text { Relative } \\
\text { payback } \\
\text { period }\end{array}$ & $\begin{array}{c}\text { Relative } \\
\text { remaining Order } \\
\text { time }\end{array}$ \\
\hline Plant A Incandescent & 428.57 & 3.67 & 1.07 & 0.75 & 1 \\
\hline Plant B Incandescent & 428.57 & 3.67 & 2.14 & 0.25 & 2 \\
\hline Plant C $\begin{array}{c}\text { Incandescent } \\
\text { 40W }\end{array}$ & 677.42 & 1.95 & 3.39 & 0.25 & 4 \\
\hline Plant D & T12/40W & 724.14 & 1.76 & 0.72 & 0.20 & 5 \\
\hline Plant E & T12/20W & 1909.09 & 0.05 & 1.91 & 0.60 & 8 \\
\hline Plant F & T12/20W & 1909.09 & 0.05 & 1.91 & 1.00 & 9 \\
\hline Plant G & T5/14W & 4200.00 & -0.52 & 2.10 & 0.50 & 10 \\
\hline Plant H & T5/28W & 1235.29 & 1.38 & 0.62 & 0.50 & 6 \\
\hline Street I HPM/250W & 1600.00 & 1.05 & 2.00 & 1.88 & 7 \\
\hline Street J HPM/400W & 1000.00 & 2.27 & 1.25 & 1.88 & 3 \\
\hline
\end{tabular}

Then the conclusion can be drawn that all should be modified except Plant $\mathrm{G}$ in terms of unlimited fund. And the corresponding modification program is as follows.
TABLE VI. THE MODIFICATION PROGRAM WITH UNLIMITED FUND

\begin{tabular}{|c|c|c|c|c|c|c|}
\hline Area & Current-used & Quantity & Benefit & Price & $\begin{array}{c}\text { Total } \\
\text { benefit in } \\
\text { each area }\end{array}$ & $\begin{array}{c}\text { Total } \\
\text { cost in } \\
\text { each } \\
\text { area }\end{array}$ \\
\hline Plant A & $\begin{array}{c}\text { Incandescent } \\
60 \mathrm{~W}\end{array}$ & 200 & 38.50 & 10.5 & 7700 & 2100 \\
\hline Plant B & $\begin{array}{c}\text { Incandescent } \\
60 \mathrm{~W} \\
\end{array}$ & 200 & 38.50 & 10.5 & 7700 & 2100 \\
\hline Plant C & $\begin{array}{c}\text { Incandescent } \\
40 \mathrm{~W}\end{array}$ & 200 & 20.50 & 10.5 & 4100 & 2100 \\
\hline Plant D & $\mathrm{T} 12 / 40 \mathrm{~W}$ & 200 & 18.50 & 10.5 & 3700 & 2100 \\
\hline Plant E & $\mathrm{T} 12 / 20 \mathrm{~W}$ & 200 & 0.50 & 10.5 & 100 & 2100 \\
\hline Plant F & $\mathrm{T} 12 / 20 \mathrm{~W}$ & 200 & 0.50 & 10.5 & 100 & 2100 \\
\hline Plant G & $\mathrm{T} 5 / 14 \mathrm{~W}$ & 200 & -5.25 & 10.5 & 0 & 0 \\
\hline Plant H & $\mathrm{T} 5 / 28 \mathrm{~W}$ & 200 & 14.50 & 10.5 & 2900 & 2100 \\
\hline Street I & $\mathrm{HPM} / 250 \mathrm{~W}$ & 400 & 104.55 & 100 & 41818.18 & 40000 \\
\hline Street J & HPM/400W & 400 & 227.27 & 100 & 90909.09 & 40000 \\
\hline
\end{tabular}

Table VI shows that the total energy-saving benefit in the factory is $159027.3 ¥$, and the cost of modification is $94700 ¥$. Thus the benefit ratio of this program is 1.68 , which means that $2.68 Y$ can be obtained with 1 Y.

At the same time, it should be emphasized that this paper proposes how to produce the optimal modification program from the angle of limited investment. If the investment is less than $94700 \mathrm{Y}$, the corresponding program can be obtained by the modification order of lighting equipment.

The investment mentioned above is $45000 \mathrm{Y}$. But users face the problem how to maximize the benefit under the limited fund.

1) If the benefit of unit lighting equipment is the only factor to be considered, the corresponding program is as follows.

TABLE VII. MODIFICATION PROGRAM BASED ON THE ORDER OF UNIT LIGHTING EQUIPMENT'S BENEFIT

\begin{tabular}{cccccc}
\hline Area & Benefit & Order & $\begin{array}{c}\text { Total } \\
\text { benefit in } \\
\text { each area }\end{array}$ & $\begin{array}{c}\text { Total cost } \\
\text { in each } \\
\text { area }\end{array}$ & Program \\
\hline Plant A & 38.50 & 3 & 0.00 & 0.00 & $\begin{array}{c}\text { Not to be } \\
\text { modified }\end{array}$ \\
\hline Plant B & 38.50 & 3 & 0.00 & 0.00 & $\begin{array}{c}\text { Not to be } \\
\text { modified }\end{array}$ \\
\hline Plant C & 20.50 & 5 & 0.00 & 0.00 & $\begin{array}{c}\text { Not to be } \\
\text { modified }\end{array}$ \\
\hline Plant D & 18.50 & 6 & 0.00 & 0.00 & $\begin{array}{l}\text { Not to be } \\
\text { modified }\end{array}$ \\
\hline Plant E & 0.50 & 8 & 0.00 & 0.00 & $\begin{array}{l}\text { Not to be } \\
\text { modified }\end{array}$ \\
\hline Plant F & 0.50 & 9 & 0.00 & 0.00 & $\begin{array}{l}\text { Not to be } \\
\text { modified }\end{array}$ \\
\hline Plant G & -5.50 & 10 & 0.00 & 0.00 & $\begin{array}{l}\text { Not to be } \\
\text { modified }\end{array}$ \\
\hline Plant H & 14.50 & 7 & 0.00 & 0.00 & $\begin{array}{l}\text { Not to be } \\
\text { modified }\end{array}$ \\
\hline Street I & 104.55 & 2 & 5227.50 & 5000.00 & $\begin{array}{c}50 \text { lamps to be } \\
\text { modified }\end{array}$ \\
\hline Street J & 227.27 & 1 & 90909.09 & 40000.00 & $\begin{array}{l}\text { All to be } \\
\text { modified }\end{array}$ \\
\hline
\end{tabular}


Table VII shows that the total energy-saving benefit in the factory is $96136.59 Y$, and the cost of modification is $45000 Y$.

2) If the payback period of unit lighting equipment is the only factor to be considered, the corresponding program is as follows.

TABLE VIII. MODIFICATION PROGRAM BASED ON THE PAYBACK PERIOD OF UNIT LIGHTING EQUIPMENT

\begin{tabular}{cccccc}
\hline Area & $\begin{array}{c}\text { Payback } \\
\text { period (h) }\end{array}$ & Order & $\begin{array}{c}\text { Total } \\
\text { benefit in } \\
\text { each area }\end{array}$ & $\begin{array}{c}\text { Total cost } \\
\text { in each area }\end{array}$ & Program \\
\hline Plant A & 428.57 & 1 & 7700.00 & 2100.00 & $\begin{array}{c}\text { All to be } \\
\text { modified }\end{array}$ \\
\hline Plant B & 428.57 & 1 & 7700.00 & 2100.00 & $\begin{array}{c}\text { All to be } \\
\text { modified }\end{array}$ \\
\hline Plant C & 677.42 & 3 & 4100.00 & 2100.00 & $\begin{array}{c}\text { All to be } \\
\text { modified }\end{array}$ \\
\hline Plant D & 724.14 & 4 & 3700.00 & 2100.00 & $\begin{array}{c}\text { All to be } \\
\text { modified }\end{array}$ \\
\hline Plant E & 1909.09 & 8 & 0.00 & 0.00 & $\begin{array}{c}\text { Not to be } \\
\text { modified }\end{array}$ \\
\hline Plant F & 1909.09 & 8 & 0.00 & 0.00 & $\begin{array}{c}\text { Not to be } \\
\text { modified }\end{array}$ \\
\hline Plant G & 4200.00 & 10 & 0.00 & 0.00 & $\begin{array}{c}\text { Not to be } \\
\text { modified }\end{array}$ \\
\hline Plant H & 1235.29 & 6 & 0.00 & 0.00 & $\begin{array}{c}\text { Not to be } \\
\text { modified }\end{array}$ \\
\hline Street I & 1600.00 & 7 & 0.00 & 0.00 & $\begin{array}{l}\text { Not to be } \\
\text { modified }\end{array}$ \\
\hline Street J & 1000.00 & 5 & 83180.82 & 36600.00 & $\begin{array}{c}366 \text { lamps } \\
\text { to be } \\
\text { modified }\end{array}$ \\
\hline
\end{tabular}

Table VIII shows that the total energy-saving benefit in the factory is $106380.32 ¥$, and the cost of modification is $45000 Y$.

3) If the modification urgency of current-used lighting equipment in each area is the only factor to be considered, the corresponding program is as follows.

TABLE IX. MODIFICATION PROGRAM BASED ON THE MODIFICATION URGENCY OF CURRENT-USED LIGHTING EQUIPMENT

\begin{tabular}{cccccc}
\hline Area & $\begin{array}{c}\text { Remaining } \\
\text { time }\end{array}$ & Order & $\begin{array}{c}\text { Total } \\
\text { benefit in } \\
\text { each area }\end{array}$ & $\begin{array}{c}\text { Total cost } \\
\text { in each } \\
\text { area }\end{array}$ & Program \\
\hline Plant A & 300.00 & 4 & 7700.00 & 2100.00 & $\begin{array}{c}\text { All to be } \\
\text { modified }\end{array}$ \\
\hline Plant B & 50.00 & 1 & 7700.00 & 2100.00 & $\begin{array}{c}\text { All to be } \\
\text { modified }\end{array}$ \\
\hline Plant C & 50.00 & 1 & 4100.00 & 2100.00 & $\begin{array}{c}\text { All to be } \\
\text { modified }\end{array}$ \\
\hline Plant D & 200.00 & 3 & 3700.00 & 2100.00 & $\begin{array}{c}\text { All to be } \\
\text { modified }\end{array}$ \\
\hline Plant E & 600.00 & 5 & 100.00 & 2100.00 & $\begin{array}{c}\text { All to be } \\
\text { modified }\end{array}$ \\
\hline Plant F & 1000.00 & 6 & 100.00 & 2100.00 & $\begin{array}{c}\text { All to be } \\
\text { modified }\end{array}$ \\
\hline Plant G & 1000.00 & 6 & -1100.00 & 2100.00 & $\begin{array}{l}\text { All to be } \\
\text { modified }\end{array}$ \\
\hline Plant H & 1000.00 & 8 & 2900.00 & 2100.00 & $\begin{array}{l}\text { All to be } \\
\text { modified }\end{array}$ \\
\hline Street I & 1500.00 & 9 & 14741.55 & 14100.00 & $\begin{array}{l}141 \text { lamps to } \\
\text { be modified }\end{array}$ \\
\hline Street J & 1500.00 & 9 & 32045.07 & 14100.00 & $\begin{array}{l}141 \text { lamps to } \\
\text { be modified }\end{array}$ \\
\hline
\end{tabular}

Table IX shows that the total energy-saving benefit in the factory is $106380.32 Y$, and the cost of modification is $45000 Y$.

4) Based on the model of economic evaluation mentioned in this paper, the corresponding program is as follows.

TABLE X. MODIFICATION PROGRAM BASED ON THE MODEL OF ECONOMIC EVALUATION

\begin{tabular}{c|c|c|c|c|c|c|c}
\hline Area & $\begin{array}{c}\text { Benefit } \\
\text { ratio }\end{array}$ & $\begin{array}{c}\text { Relative } \\
\text { payback } \\
\text { time }\end{array}$ & $\begin{array}{c}\text { Relative } \\
\text { remaining } \\
\text { time }\end{array}$ & $\begin{array}{c}\text { Total } \\
\text { benefit } \\
\text { in each } \\
\text { area }\end{array}$ & $\begin{array}{c}\text { Total } \\
\text { cost in } \\
\text { each } \\
\text { area }\end{array}$ & Order & Program \\
\hline Plant A & 3.67 & 1.07 & 0.75 & 7700.00 & 2100 & 1 & $\begin{array}{c}\text { All to be } \\
\text { modified }\end{array}$ \\
\hline Plant B & 3.67 & 2.14 & 0.25 & 7700.00 & 2100 & 2 & $\begin{array}{c}\text { All to be } \\
\text { modified }\end{array}$ \\
\hline Plant C & 1.95 & 3.39 & 0.25 & 1558.00 & $\begin{array}{c}798.0 \\
0\end{array}$ & 4 & $\begin{array}{l}76 \\
\text { to lamps } \\
\text { modified }\end{array}$ \\
\hline Plant D & 1.76 & 0.72 & 0.20 & 0.00 & 0.00 & 5 & $\begin{array}{l}\text { Not to be } \\
\text { modified }\end{array}$ \\
\hline Plant E & 0.05 & 1.91 & 0.60 & 0.00 & 0.00 & 8 & $\begin{array}{l}\text { Not to be } \\
\text { modified }\end{array}$ \\
\hline Plant F & 0.05 & 1.91 & 1.00 & 0.00 & 0.00 & 9 & $\begin{array}{l}\text { Not to be } \\
\text { modified }\end{array}$ \\
\hline Plant G & -0.52 & 2.10 & 0.50 & 0.00 & 0.00 & 10 & $\begin{array}{l}\text { Not to be } \\
\text { modified }\end{array}$ \\
\hline Plant H & 1.38 & 0.62 & 0.50 & 0.00 & 0.00 & 6 & $\begin{array}{l}\text { Not to be } \\
\text { modified }\end{array}$ \\
\hline Street I & 1.05 & 2.00 & 1.88 & 0.00 & 0.00 & 7 & $\begin{array}{l}\text { Not to be } \\
\text { modified }\end{array}$ \\
\hline Street J & 2.27 & 1.25 & 1.88 & 90909 & 40000 & 3 & $\begin{array}{l}\text { All to be } \\
\text { modified }\end{array}$ \\
\hline
\end{tabular}

Table $\mathrm{X}$ shows that the total energy-saving benefit in the factory is $107867.09 Y$, and the cost of modification is $45000 Y$.

The conclusion can be drawn that the optimal energysaving modification program can be obtained in terms of energy-saving benefit, relative payback period and annual running time. There's a little deviation between the effect of total energy-saving benefit and the reality, because the total energy-saving benefit is not obvious in real life. The main reasons include the price of energy-saving equipment and the discount rate which are a little higher, and the installation cost ignored.

The actual situation is as follows. Firstly, the cost of modification is $45000 Y$. Secondly, the overall discount rate of benefit is $15 \%$. Thirdly, the price of CFL and HPS has been double. Lastly, the installation cost of every 10 energy-saving lighting equipment is $5 ¥$. Thus the total energy-saving benefit of the optimal program is 16568.66 $¥$, which means that the benefit ratio of this program is 0.37 . The total energy-saving benefit of the optimal program matches the actual situation in real life, which means that the economic evaluation of this paper is practical and reliable.

\section{CONCLUSIONS}

This paper sets up the economic evaluation in terms of three major indexes including benefit ratio, relative payback period of investment and relative remaining time. The constraint condition of economic evaluation is investment, and the goal is to get the best total energy- 
saving benefit after modification. Thus, the optimal program can be selected according to investment and objects for modification. So the economic evaluation can be applied to other lighting equipment because the lighting equipment has general character.

Of course, a good energy-saving program is the foundation of saving energy, when it has good performance on economic evaluation. However the key to save energy depends on users. When users are aware of the importance of saving energy, the energy-saving effect is much better than that of the technological modification based on the economic evaluation.

\section{REFERENCES}

[1] http://www.china-esi.com/Pat/List/List_157.html (accesed August 26,2010).

[2] LI Hui-qun, ZHOU Chun-yan, "Summary of electronic energy-saving lamps," Energy-saving technology, vol.22, no. 124 , pp: $64-65,2004$. (in Chinese)

[3] Herbert A. Simon, "A Behavioral Model of Rational Choice," The Quarterly Journal of Economics, Vol. 69, no. 1, pp: 99-118, February 1955.

[4] GB/T 13471-2008, Power-saving method of calculating and evaluating the technical and economic benefits. (in Chinese)

[5] Grant, Eugene L, Principles of engineering economy. Oxford University Press, 1990.

[6] Mansfield, Edwin, Managerial economics: Theory, applications, and cases. Mill Norton, CA: Managerial economics, 1996.

[7] LIU Yun, "Study of Decision Support System of Savingpower of Industrial Enterprise," Master Degree Paper of Wuhan University, Wu'han, 2004, pp:9-31. (in Chinese)

[8] Marenjak S, Krstic H, "Sensitivity analysis of facilities life cycle costs," Tehnicki vjesnik-technical gazette, Vol. 17, no. 4, pp: 481-487, December 2010.

[9] Waghmode L, Sahasrabudhe A, Kulkarni P, Krstic H, "Life Cycle Cost Modeling of Pumps Using an Activity Based Costing Methodology," MECHANICAL DESIGN, Vol. 132, no. 12, pp: 121-130, November 2010.

[10] Kamal Haddad, William Sterk, Anne Wu, "Capital Budgeting Practices of Taiwanese Firms," International Management Studies, Vol. 5, no. 1, pp: 178-182, April 2010.

[11] TP Handayam, "A New Systematic Method for Optimal Heat Recovery Networks Design with Minimum Area and Exergy Loss," Applied Sciences, Vol. 10, no. 21, pp: 2737 2740, March 2010.

[12] Katharina Bunse, Julia Sachs, and Matthias Vodicka, "Evaluating Energy Efficiency Improvements in Manufacturing Processes," Advances in Production Management, pp: 19-26, January 2010.
[13] Alka Bramhandkar, "Payback Adjusted Net Present Value," New York State Economics Association, Vol. 61, pp: 3-9, October 2008.

[14] Lushu Li, K. K. Lai, "A fuzzy approach to the multiobjective transportation problem," Computers \& Operations Research, Vol. 27, no. 1, pp: 43-57, January 2000.

[15] Guisseppi A. Forgionne, "Decision technology systems: A vehicle to consolidate decision making support," Information Processing \& Management, Vol. 27, no. 6, pp: 679-697, 1991.

[16] Ramesh Sharda, Steve H. Barr, and James C. McDonald, "Decision support system effectiveness: a review and an empirical test," Management Science, Vol. 34, no. 2, pp: 139-159, February 1988.

[17] C.LHwang and K.S.Yoon, Multiple Decision Making, Springer-Verlag, Beriin 1981.

[18] "Energy-saving lamp ballast primary materials," http://www.docin.com/p-2346367.html\#documentinfo (accesed August 26,2010).

[19] http://www.taobao.com/ (accesed August 26,2010).

Yuan Yang is pursuing the B.S. degree in Institute of Electrical and Information of Jinan University, Zhuhai, China. His research interests are in the area of comprehensive automation in electrical power system.

Wei-hua Li received the M.S degree in school of electrical engineering at Southwest Jiaotong University, in July, 2006. He is currently an instructor of Electrical engineering at Zhuhai College of Jinan University, and now is pursuing the PH.D. degree in School of Electric Power at South China University of Technology, Guangzhou, China. His research interests are in the area of comprehensive automation in electrical power system.

Xin-zheng Zhang received the Ph.D. degrees from The Hong Kong Polytechnic University in 2009. He is currently a lecturer at Jinan University, Zhuhai Campus. His research interests include SLAM, autonomous mobile robots, computer vision, machine learning and cognitive science.

Chu-qi Yang is pursuing the B.S. degree in International Business School of Jinan University, Zhuhai, China. Her research interests are in the area of comprehensive automation in electrical power system.

Dong $\mathbf{L v}$ is pursuing the B.S. degree in Institute of Electrical and Information of Jinan University, Zhuhai, China. His research interests are in the area of comprehensive automation in electrical power system.

Hai-qiang Liao is pursuing the B.S. degree in Institute of Electrical and Information of Jinan University, Zhuhai, China. His research interests are in the area of comprehensive automation in electrical power system.

Lin Yang is pursuing the B.S. degree in Beijing Institute Of Technology, Zhuhai, China. His research interests are in the area of comprehensive automation in electrical power system. 